\title{
THE EVALUATION OF THE STUDENTS' ATTITUDES AND BEHAVIOR TOWARDS FAST FOOD CONSUMPTION
}

\author{
Zehra Meliha Tengiz, Yasemin Oraman* \\ Department of Agricultural Economics, Agricultural Faculty, Namik Kemal University, Tekirdag, Turkey, \\ e-mail: yoraman@nku.edu.tr
}

\begin{abstract}
People have different lifestyles that cause different needs and desires. Lifestyles influence people's purchasing behavior. Conditions affecting lifestyles, such as long working hours, short break times, lack of cooking time and no cooking place for employees and students have an impact on changing their eating habits. This situation has led consumers to prefer products that can be consumed faster. University students are considered as significant customer potential by fast food sector. The purpose of this study was to determine whether there is a relationship between the lifestyle and the reasons for choosing fast food of university students. The data were collected by conducting a survey with 347 students in Tekirdag Namik Kemal University. The data was analyzed statistically in terms of descriptive and inferential statistics. In this direction, factors related to fast food consumption are 4 factors (product features, space, accessibility, personal satisfaction) and lifestyles are collected under 6 factors (thinkers, experiencers, achievers, believers, innovators, makers). The relationship's existence is explained by using factor scores calculated by factor analysis in a multiple regression model. According to research findings, product features variable is effective in choosing fast food products by Thinkers. Accessibility variable is affective in choosing fast food products by people who have Experiencers lifestyle; space and personal satisfaction are affective on Achievers. Product features and space are affective in choosing fast food products by Innovators. When the findings are generally evaluated; the effects of lifestyle on the causes of fast food consumption seem to be significant.
\end{abstract}

Keywords: fast food, lifestyle, consumption, consumer behavior, Vals 2

\section{Introduction}

The well-known psychologist Abraham Maslow mentions that in the hierarchy of needs, the first step cannot be overcome without the need for eating, drinking and sheltering with physiological needs (Kula, Cakar, 2015). As with all things, physiological needs vary from person to person. At this point, the concept of consumer behavior comes to the fore. Consumer behavior, goods and services purchased to meet the needs of people; why, how, when they show up. The determination of consumer behaviors precisely determines the direction of the consumer's needs and desires. In a market, where relatively standard products and services are offered, especially fast food, it is necessary to respond quickly to customer expectations (Eroglu et al., 2012; Hamsioglu, 2013). Businesses, customers, according to the desire, needs and expectations, in order to produce different solutions to be able to analyze their customers is an important point (Korkmaz, 2005).

One of the personal values that affect consumer behavior is lifestyle. The concept of lifestyle is a term that people use to describe their own or others' behavior. The most prominent feature of the concept is that it includes behavior patterns that make people different from each other (Mucuk, 2010). Lifestyle, consumer behavior literature, how people live, time and money spent on how to spend with the patterns; it includes the activities, interests and ideas of individuals (Plummer, 1974). Consumption behaviors of individuals who have grown up in the same culture and have the same age and same profession are different (Ercis et al., 2007).

Lifestyle psychography techniques are tried to be measured. One of the most common methods of psychographic segmentation is the Values, Attitudes and Lifestyle 2 (VALS 2) model. The VALS 2 model tries to explain why consumers buy and make decisions as well as what they buy. It was created to better analyze consumer behavior. The main determinants are motives, perceptions, learning, beliefs, attitudes and personality. VALS 2 model is divided into 8 groups. Each of these groups have similar characteristics in themselves (Odabasi, Baris, 2013). Businesses learn about the product and brand preferences of the consumers in accordance with the characteristics of these groups and prepare marketing mixes.

These groups are described below (Hamsioglu, 2013; Yesiloglu, 2013; Anonymous, 2018):

1. Innovators - they are highly respected, successful and responsible people. They are fond of freedom and active consumers. The purchases reflect their enhanced tastes for their senior niche products and services.

2. Thinkers - they think well before they make a decision and they do very well. They do not give importance to prestige and image. Revenues are available to purchase many products, but the durability of the product is more important than the restraints and purchases.

3. Achievers - they have a goal-oriented lifestyles, are deeply committed to their family. They are active buyers in the market with many requests and needs. For this reason, they prefer prestigious, high quality brands and products that will show their success. They read about business, news, personal development.

4. Empiricists - young and enthusiastic. They like exciting things. Their political knowledge is limited and they are uncertain about what they will believe. They spend most of their income to socialize and have fun. They like the risk. They make instant purchases according to their impulses. They pay close attention to ads.

5. Believers - they have a routine life. They are slow in changing their habits. They are strictly committed to their traditions. They do not go beyond the products they 
know. Believers prefer known products and brands. Those who strive; their image consciousness is high. They quickly get bored and move without thinking, so for those who strive, money means success. However, the money they can use arbitrarily is limited. They buy imitations of rich brands. They spend on clothing and personal care products. They prefer to read television. 6. Makers - they are motivated by expressing themselves. For this reason, they deal with handicrafts, home construction, child care. They make purchases about general needs. They are politically conservative and skeptical about new ideas.

7. Survivors - people with low levels of education and lack of skills and social life are coy. Since they do not have much income, they are satisfied with their basic needs. They are content with what they do in life. Coupons are common and follow discounts.

The most important feature of the concept of lifestyle is that it is dynamic; because the technological, economic, social trends and cultural changes of the society reflect on the lifestyles of consumers and change their way of life. These changes have led to the development of some sectors. Fast food sector is one of the developing sectors thanks to these changes. Rapid urbanization in living conditions, getting closer to western culture, increasing the number of women working, and the desire to save time have also gained importance in this sector.

Fast food is food, which can be prepared quickly and easily and is sold at commercial undertakes such as restaurants and snack bars (Vogli et al., 2014). Western fast food items prevalently are hamburger, pizza, pasta, sandwiches, French fries, fried chicken, tacos, and hot dogs. Traditional fast foods in Turkey are meat on a spit, pide, steak tartar a turca, lahmacun, Turkish bagel, meatball, grilled sheep's intestines, and stuffed mussels (Beak at al., 2006; Driskell at al., 2006; San, 2009; Haines at al., 2010; Akdag, 2015).

In the studies for fast food consumption, which has increased rapidly over time (Korkmaz, 2005; San, 2009; Kayisoglu, Icoz, 2012; Kingir et al., 2015; Lassen et al., 2016; Tengiz, 2018); according to the elderly, the highincome people compared to the low-income, compared to the low level of education of the high-educated men, according to the women, according to the married women, working women prefer to eat more fast food than housewives. These studies reflect the relationship between activity and demographic characteristics and fast food consumption.

Previous studies have shown that the consumption of fast food products is more than that of other age groups, especially in young age students (Driskell et al., 2006; Hamsioglu, 2013; Comert, 2014; Akdag, 2015; Lassen et al., 2016). University students have the most important share in the fast food sector (Beak et al., 2006). Since the students start their university education, they become familiar with the environment and become more open to interact with the environment. This period is especially the period when the consumption of fast food products increases. Students want to make friends, socialization, cheap and satisfying products, being served fast, not wanting to cook and especially those who stay in dormitories cannot have the appropriate environment for cooking causes fast food products are more preferred.

The purpose of this study was to determine whether there is a relationship between the lifestyle and the reasons for choosing fast food of university students. In other words, the reasons for fast food consumption, which may change depending on the lifestyle of consumers were determined.

\section{Materials and Methods}

In this study, data obtained from 347 university students in 2015-2016 in Tekirdag Namik Kemal University were used. In order to collect the original data, appropriate questionnaire forms were prepared and applied to the sample volume.

The VALS 2 scale (Plummer, 1974; Lin, 2003; Ozgul, 2010; Hamsioglu, 2013; Valentine, Powers, 2013; Yesiloglu, 2013; Guner, 2014) determined the lifestyles of the respondents from various literature reviews on the reasons for choosing fast food products (Madran, Kabakci, 2002; Driskell et al., 2006; Kaya, 2011; Comert, 2014).

The questionnaire used in the study consists of four parts. The first part involved closed-ended questions, such as frequency and time of arrival of consumer in enterprise, whether there had been a change in consumption in recent years, their usual preference of fast food products. The second part was focused on the reasons why consumers preferred fast food products. The third part consisted of questions on lifestyle. Likerttype five-point scales were used. The last part of the questionnaire contained questions that determine demographic characteristics of consumers.

The data obtained from the study were analyzed with SPSS 23.0 package program. In this context, chi-square, factor analysis and multiple linear regression were used. Factor analysis was applied to determine whether the variables used in the study were compatible with each other, and to present the data in a more meaningful and abstract manner. Varimax rotation method was used in the analysis of the basic components.

The existence of the relationship between consumer lifestyle and the reasons of fast food consumption was explained by using factor analysis scores calculated by factor analysis in multiple regression model. Enter method was used in the analysis.

\section{Results and Discussion}

When the demographic characteristics of the consumers were examined, $63.7 \%$ of the study was female and $36.3 \%$ was male. Since the study was applied to university students, they stated that they did not work $(86.2 \%)$. It was seen that $54.5 \%$ of the consumers received a scholarship or a repayment loan from the Turkish Government or a private institution. $44.1 \%$ of the respondents live at home, $38.9 \%$ live in dormitories and $17.0 \%$ live in the apartments. Most of the consumers live alone $(14.4 \%)$ or with friend $(65.4 \%)$ away from 
their families (Table 1). Consumers consume fast food products several times a week $(36.0 \%)$. Consumption is 1-2 times a month and has a share of $22.0 \%$ in total consumption. The number of people consuming each day $(15.0 \%)$ and once a week $(16.0 \%)$ is very close to each other. Haines et al. (2010) stated that $84.0 \%$ of the students consumed fast-food products at least once a week.

Table 1

Demographic characteristics of the students

\begin{tabular}{llll}
\hline Parameters & & Frequency & \% \\
\hline Gender & Male & 126 & 36.3 \\
& Female & 221 & 63.7 \\
\hline Working situation & Not working & 299 & 86.2 \\
& Part-time & 26 & 7.5 \\
& Full-time & 22 & 6.3 \\
\hline Monthly & Less than 300 £ & 36 & 10.4 \\
expenditure & $301-500 €$ & 110 & 31.7 \\
& $501-1000 €$ & 141 & 40.6 \\
& 1001 £+ & 60 & 17.3 \\
\hline Scholarship & Yes & 189 & 54.5 \\
& No & 158 & 45.5 \\
\hline Living place & Home & 153 & 44.1 \\
& Dormitory & 135 & 38.9 \\
& Student apartment & 59 & 17.0 \\
\hline Living with who & with family & 60 & 17.3 \\
& with friend & 227 & 65.4 \\
& alone & 50 & 14.4 \\
& with a relative & 10 & 2.9 \\
\hline
\end{tabular}

Dalrymple and Dyett (2013) concluded that the majority of students $(91.8 \%)$ consume fast food once or twice a week. $36.9 \%$ of consumers consumed fast food during the week, $33.7 \%$ at the weekend and $29.4 \%$ at weekends and at the weekend. $65.0 \%$ of males and $68.0 \%$ of females stated that their consumption of fast food consumption increased due to the impact of university life. Nearly all of the consumers $(87.9 \%)$ are aware of the harmful effects of fast food products on health. Haines et al. (2010) reported that university students often consume fast food products and pay more for nutritious intense choices $(88.0 \%)$, but they do not prefer to pay because of habit and taste factors. The frequency of sex and consumption according to the chi square independence test results $\left(\mathrm{x}^{2}: 3.918 ; \mathrm{p}<0.05\right)$, consumption time $\left(\mathrm{x}^{2}: 2.165 ; \mathrm{p}<0.05\right)$ and the effect of university on consumption $\left(\mathrm{x}^{2}: 0.517 ; \mathrm{p}<0.05\right)$ No significant relationship was found. However, it was concluded that the effect of fast food products on health was a difference between sex ( $\left.x^{2}: 11.211 ; \mathrm{p}>0.05\right)$. Women find food more harmful than men. Figure 1 shows which enterprises preferred by consumers. San (2009) has identified fast food restaurants as Burger King and Mc Donald's, which are most preferred by consumers. In South Korea, it was found that sandwiches, hamburgers and fries were frequently consumed in western fast food foods (Wyne et al., 1994). Consumers are most interested in health $(23.7 \%)$ and quality $(22.3 \%)$ of the products. In the third row, the prices of the products $(16.3 \%)$ are in place and the flavor $(13.7 \%)$ is the fourth.

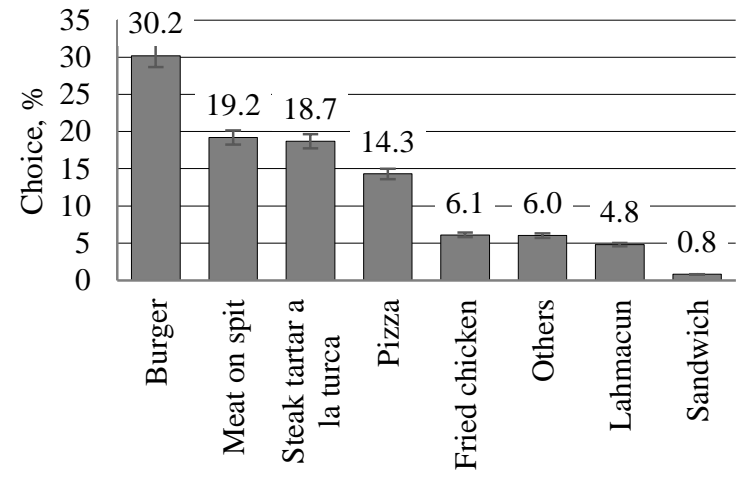

Figure 1. Choice of fast food types

Another study conducted in the United States revealed that fast food products are consumed because they are perceived as low cost and economic; lack of time, taste and eating with family and friends have been stated as the reasons (Morse, Driskell, 2009). Lassen et al. (2016) in their study in Denmark indicated habits, price and taste as the most effective factors in the choice of fast food products. Cronbach Alfas Alpha coefficient of the scale for fast food consumption was found to be 0.819 . Accordingly, the internal consistency of the variables within the scale is high. If $0.60 \leq \alpha \leq 0.80$, the scale is quite reliable (Kalayci 2014).

Kaiser-Meyer-Olkin (KMO) competence sample coefficient was 0.812 . The obtained coefficient shows that the data are suitable for factor analysis. The chi-square value of Bartlett's sphericity test is 1880.353. As result of the analysis variables were collected under 4 factors explaining the total variance value of $51.7 \%$. The contributions of the variables to the main factors obtained from the analysis and the explained variances are shown in Table 2. The 1st factor after rotation is called Effect of Product Properties. These 6 items explain $15.8 \%$ of the total variance. The second factor after rotation is called Space Effect. These 4 items explain $12.7 \%$ of the total variance. The third factor after rotation is called the Accessibility Effect. These 5 items explain $13.8 \%$ of the total variance. The post-rotation factor, which has a major effect on the 4th factor, is to reward myself and this factor is called The Effect of Personal Satisfaction. These 4 items explain $9.3 \%$ of the total variance.

Cronbach's Alpha of the scale related to lifestyles was found to be 0.761 . The KMO competence sample was 0.821 . The chi-square value of Bartlett's sphericity test is 1985.977 and its significance is $p<0.000$. As a result of the analysis, 21 variables were revealed which accounted for $59.6 \%$ of the total variance and were collected under 6 factors. The contributions of the variables to the main factors obtained from the analysis and the explained variances are shown in Table 3 . The 1st factor after rotation is called Thinkers. These 7 items explain $19.8 \%$ of the total variance. The second factor after rotation is called Experiencers. This fourth article explains $10.2 \%$ of the total variance. The third factor after rotation is named Successors. 
Results of factor analysis in fast food consumption causes

\begin{tabular}{|c|c|c|c|}
\hline & FS & PTVE & EV \\
\hline Factor F1: Effect of Product Properties & & 15.813 & 3.005 \\
\hline Products are of good quality & 0.831 & & \\
\hline Clean and hygienic & 0.823 & & \\
\hline Prices are appropriate & 0.610 & & \\
\hline Servings are hearty & 0.582 & & \\
\hline It is delicious & 0.519 & & \\
\hline Product variety & 0.504 & & \\
\hline Factor F2: Space Effect & & 12.662 & 2.630 \\
\hline Since it helped me to socialize & 0.786 & & \\
\hline For me there are similar people & 0.772 & & \\
\hline Seating layout for being spacious & 0.638 & & \\
\hline Gifts for offers & 0.594 & & \\
\hline FactorF3: Accessibility Effect & & 13.845 & 2.406 \\
\hline Easy to access & 0.777 & & \\
\hline For fast service & 0.684 & & \\
\hline You can order from the phone & 0.614 & & \\
\hline I don't have time to prepare food & 0.587 & & \\
\hline Products standard & 0.364 & & \\
\hline Factor F4: Effect of Personal Satisfaction & & 9.342 & 1.775 \\
\hline I reward myself & 0.747 & & \\
\hline I'm used to the taste & 0.558 & & \\
\hline For being a chain & 0.517 & & \\
\hline I don't know how to cook & 0.439 & & \\
\hline
\end{tabular}

Result of Factor Analysis in Lifestyles

\begin{tabular}{|c|c|c|c|}
\hline & FS & PTVE & $\mathbf{E V}$ \\
\hline Factor Y1: Thinkers & & 19.799 & 4.158 \\
\hline My family comes first to me. & 0.792 & & \\
\hline I'm open to new ideas. & 0.735 & & \\
\hline I value social values. & 0.704 & & \\
\hline I act in accordance with my budget for shopping. & 0.671 & & \\
\hline I prefer quality and time-saving products. & 0.654 & & \\
\hline I think well before decide. & 0.614 & & \\
\hline I follow the events in the country and the world closely. & 0.550 & & \\
\hline Factor Y2: Experiencers & & 10.188 & 2.140 \\
\hline I like the risk. & 0.794 & & \\
\hline I spend a lot of money to have fun and socialize. & 0.648 & & \\
\hline I'm fond of my freedom. & 0.620 & & \\
\hline I like exciting things. & 0.551 & & \\
\hline Factor Y3: Achievers & & 9.718 & 2.041 \\
\hline I follow fashion closely. & 0.709 & & \\
\hline I expect approval from others in a job that I do. & 0.654 & & \\
\hline Money means success for me. & 0.643 & & \\
\hline I prefer branded products. & 0.613 & & \\
\hline Factor Y4: Believers & & 6.928 & 1.455 \\
\hline I don't go beyond my usual lifestyle. & 0.830 & & \\
\hline I'm not out of the products I know. & 0.809 & & \\
\hline Factor Y5: Innovators & & 6.617 & 1.389 \\
\hline I follow the innovations. & 0.706 & & \\
\hline I want to be the leader in my friends. & 0.674 & & \\
\hline Factor Y6: Makers & & 6.378 & 1.339 \\
\hline I am skilled in machine repair and maintenance. & 0.731 & & \\
\hline I like to do dexterity. & 0.622 & & \\
\hline
\end{tabular}

FS - Factor Score; PTVE - Percent of Total Variance Explained; EV -Eigen value 
These 4 items explain $9.7 \%$ of the total variance. The 4 th factor after rotation was called Believers. These two items explain $6.9 \%$ of the total variance. The fifth factor after rotation is called Innovators. These two items explain $6.6 \%$ of the total variance. The 6 th factor after rotation is called Makers. These two items explain $6.3 \%$ of the total variance.

For main hypothesis, lifestyles and some demographic activities were regulated on factors related to consumption reasons and Table 4 was reached.

Table 4

Regression results for lifestyle and fast food consumption reasons

\begin{tabular}{|c|c|c|c|c|c|c|c|c|c|c|c|c|c|c|}
\hline \multirow{6}{*}{ 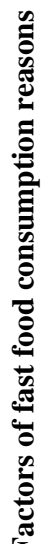 } & \multicolumn{7}{|c|}{ Factors of lifestyle } & \multicolumn{4}{|c|}{ Demographic characteristics } & \multirow[b]{2}{*}{$\mathrm{R}^{2}$} & \multirow[b]{2}{*}{$\mathrm{F}$} & \multirow[b]{2}{*}{$\begin{array}{c}\text { F } \\
\text { value } \\
\text { (Sig.) }\end{array}$} \\
\hline & & 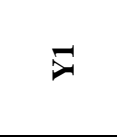 & 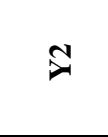 & $\ddot{\gamma}$ & $\underset{\nabla}{ }$ & $\approx$ & $\ddot{\nu}$ & 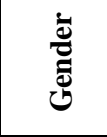 & $\frac{n}{\tilde{E}}$ & 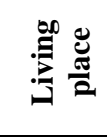 & 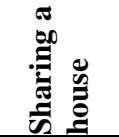 & & & \\
\hline & $\mathrm{F} 1$ & $\begin{array}{c}0.276 \\
(\mathbf{0 . 0 0 0}) \\
\end{array}$ & $\begin{array}{c}0.052 \\
(0.328) \\
\end{array}$ & $\begin{array}{c}0.051 \\
(0.324) \\
\end{array}$ & $\begin{array}{l}-0.056 \\
(0.278) \\
\end{array}$ & $\begin{array}{c}0.105 \\
(\mathbf{0 . 0 4 2})\end{array}$ & $\begin{array}{l}-0.024 \\
(0.637)\end{array}$ & \begin{tabular}{|l|}
-0.293 \\
$(\mathbf{0 , 0 1 3 )}$ \\
\end{tabular} & $\begin{array}{l}-0.037 \\
(0.433) \\
\end{array}$ & $\begin{array}{c}0.132 \\
(0.315) \\
\end{array}$ & $\begin{array}{c}-0.376 \\
(\mathbf{0 . 0 1 6}) \\
\end{array}$ & 0.160 & 4.867 & 0.000 \\
\hline & $\mathrm{F} 2$ & $\begin{array}{c}-0.172 \\
(\mathbf{0 . 0 0 1})\end{array}$ & $\begin{array}{c}0.001 \\
(0.979)\end{array}$ & $\begin{array}{c}0.141 \\
(\mathbf{0 . 0 0 8})\end{array}$ & $\begin{array}{l}-0.061 \\
(0.250)\end{array}$ & $\begin{array}{c}0.150 \\
(\mathbf{0 . 0 0 5})\end{array}$ & $\begin{array}{c}0.024 \\
(0.652)\end{array}$ & $\begin{array}{c}0.029 \\
(0.812)\end{array}$ & $\begin{array}{l}-0.068 \\
(0.161)\end{array}$ & $\begin{array}{l}-0.470 \\
(\mathbf{0 . 0 0 1})\end{array}$ & $\begin{array}{c}0.453 \\
(\mathbf{0 . 0 0 5})\end{array}$ & 0.119 & 3.444 & 0.000 \\
\hline & F3 & $\begin{array}{l}-0.710 \\
(\mathbf{0 . 0 0 0})\end{array}$ & $\begin{array}{c}0.352 \\
(\mathbf{0 . 0 0 0})\end{array}$ & $\begin{array}{c}0.199 \\
(0.922)\end{array}$ & $\begin{array}{l}-0.005 \\
(0.281)\end{array}$ & $\begin{array}{l}-0.054 \\
(0.075)\end{array}$ & $\begin{array}{c}0.089 \\
(0.497)\end{array}$ & $\begin{array}{c}0.034 \\
(\mathbf{0 . 0 1 6})\end{array}$ & $\begin{array}{c}0.276 \\
(\mathbf{0 . 0 3 2})\end{array}$ & $\begin{array}{l}-0.091 \\
(0.833)\end{array}$ & $\begin{array}{c}-0.027 \\
(0.437)\end{array}$ & 0.208 & 6.712 & 0.000 \\
\hline & F4 & $\begin{array}{l}-0.178 \\
(\mathbf{0 . 0 0 1})\end{array}$ & $\begin{array}{c}0.087 \\
(0.108)\end{array}$ & $\begin{array}{c}0.206 \\
(\mathbf{0 . 0 0 0})\end{array}$ & $\begin{array}{l}-0.109 \\
(\mathbf{0 . 0 3 7})\end{array}$ & $\begin{array}{c}0.098 \\
(0.063)\end{array}$ & $\begin{array}{c}0.046 \\
(0.382)\end{array}$ & $\begin{array}{c}0.166 \\
(0.165)\end{array}$ & $\begin{array}{c}0.001 \\
(0.980)\end{array}$ & $\begin{array}{l}-0.170 \\
(0.201)\end{array}$ & $\begin{array}{c}0.342 \\
(\mathbf{0 . 0 3 0})\end{array}$ & 0.135 & 3.980 & 0.000 \\
\hline
\end{tabular}

F1 - Effect of Product Properties, F2 - Space Effect, F3 - Accessibility Effect, F4 - Effect of Personal Satisfaction; Y1 - Thinkers, Y2 - Experiencers, Y3 - Achievemers, Y4 - Believers, Y5 - Innovators, Y6 - Makers; F- F Value

In the table, the explanations between the variables $\left(\mathrm{R}^{2}\right)$, $\beta$ coefficients and the significance levels in parentheses, and the $F$ test statistic values and significance levels for the determination of dependent and independent variables as a whole are included. Multiple linear regression assumptions are met between factors related to the reasons of fast food consumption (dependent variable) and lifestyle factors.

The main hypothesis:

$H_{1}$ : There is no relationship between consumer lifestyles and the reasons of consumption of fast food products;

$\mathrm{H}_{2}$ : There is a relationship between consumer lifestyles and the reasons of consumption of fast food products.

According to Table 4, the change in lifestyle factors and demographic variables explained $16.0 \%$ of the change in factor due to the effect of product characteristics. The remaining $84.0 \%$ is explained by the variables not included in the study. The fact that the F test statistic value (Sig.) It indicates that it is meaningful to explain the effect of product characteristics with lifestyles $(p \geq 0.000)$. Factors related to lifestyle and changes in demographic variables; It can explain $11.9 \%$ of the change in the effect of the space, $20.8 \%$ of the change in accessibility effect and $13.5 \%$ of the change in the personal satisfaction factor. In addition, lifestyle factors and change in demographic factors were significant in the $95.0 \%$ confidence interval in explaining changes in factors related to fast food consumption. With this finding, the hypothesis of the study is rejected

\section{Conclusions}

Fast food products of university students who have lifestyle in the thinker's factor; it prefers the effect of the product characteristics and the effect of accessibility. In other words, thinkers prefer fast food foods for reasons such as high quality, clean, hygienic, affordable, satisfactory portion of the products, ease of transportation. It has a negative effect on space effect. Thinkers are generally well-educated, mature and satisfied individuals because they do not find the idea of socialization sufficient. The effects of personal satisfaction for thinkers are not important for fast food consumption. The students who have a lifestyle in terms of experience are fast food products; While preferring the effect of the product characteristics due to the effect of accessibility and personal satisfaction effect, it does not consider the variables related to the space effect important. For consumers with a successful lifestyle, the reasons of fast food consumption include socialization, the spaciousness of the seating, the delicious products and the self-reward. Fast food products are preferred by successful, responsible and self-respecting innovators because of similar quality, clean and satisfactory products. For the consumers in the group of believers and makers, no meaningful result could be obtained regarding the reasons of fast food consumption.

There is no similar study in this area in Tekirdag, which is the study area. Namik Kemal University is the only university in Tekirdag. The number of students increases every year due to the fact that the university grows day by day and the province is close to major cities such as Istanbul. This situation depends on product and service features such as fast food restaurants; fast service, cheap, delicious and hearty portions, depending on the characteristics of the venue; spacious seating arrangements are indicative of a further increase in requests such as spacious.

As result, this study can guide the preparation of marketing activities for the target groups based on the lifestyles of university students who are the most important potential customers of existing or new fast 
food restaurants. In addition, it is contributing in the studies to be carried out after this study.

\section{References}

1. Akdag H.N. (2015) Lise ogrencilerinin fast food Tuketim Durumlarinin ve Aliskanliklarinin Saptanmasi. MSc. Thesis, Okan Universitesi Saglik Bilimleri Enstitusu, Istanbul, p. 33-38.

2. Anonymous (2018) Strategic business insights. [last accessed on 20.01.2018]. Available: http://www.strategicbusinessinsights.com/vals/ustypes.sh tml.

3. Beak S.H., Ham S., Yang I.S. (2006) A Cross-cultural comparison of fast food restaurant selection criteria between Korean and Filipino college students. International Journal of Hospitality Management, Vol. 25(4), p. 683-698.

4. Comert M. (2014) Genclerin fast food Tuketim Aliskanliklari. Akademik Sosyal Arastirmalar Dergisi, Vol. 2(6), p. 423-427.

5. Dalrymple K., Dyett P. (2013) Eating practices and nutrition knowledge among university students. Student Project. The University of the West İndies, p. 33-36.

6. Driskell J.A., Meckna B.R., Scales N.E. (2006) Differences exist in the eating habits of university men and women at fast-food restaurants. Nutrition Research, Vol. 26(10), p. 524-530.

7. Ercis A., Unal S., Polat C. (2007) Yasam tarzlarinin satin alma karar sureci uzerindeki rolu. Ataturk Universitesi Iktisadi ve Idari Bilimler Dergisi, Vol. 21(2), p. 281-311.

8. Eroglu E., Velioglu M.N., Baris G., Argan M. (2012) Tuketici Davranislari. Eskisehir: Acikogretim Fakultesi Yayini No: 1572, $186 \mathrm{p}$.

9. Guner A.G. (2014) Tuketici kulturu cercevesinde Yasam Tarzinin Onemi ve Marka Tercihi: Bir Arastirma. MSc. Thesis, Galatasaray Universitesi Sosyal Bilimler Enstitusu, Istanbul, p. 94-100.

10. Haines C., O’Neil C.E., Zanovec M. (2010) Fast-food consumption among college students and their attitudes toward healthier fast-food options. The Federation of American Societies for Experimental Biology Journal, Vol. 24(1).

11. Hamsioglu A.B. (2013) Fast food Urunleri Satin Alan Tuketicilerin Yasam Tarzlarini Belirlemeye Yonelik Bir Uygulama. Uluslararasi Iktisadi ve Idari Incelemeler Dergisi, Vol. 11, p. 17-34.

12. Kalayci S. (2014) SPSS Uygulamali Cok Degiskenli Istatistik Teknikleri. Ankara: Asil Yayinlari, 426 p.

13. Kaya D. (2011) Hizli yiyecek tuketicilerinin hizli yiyecek tuketme nedenleri: mersin sehir merkezinde faaliyet gosteren yerel, ulusal, uluslararasi zincir hizli yiyecek isletme musterileri uzerinde bir arastirma. MSc. Thesis, Mersin Universitesi Sosyal Bilimler Enstitusu, Mersin, p. 71-88.

14. Kayisoglu S., Icoz A. (2012) Egitim Duzeyinin Fast Food Tuketim Aliskanligina Etkisi. Tekirdag Ziraat Fakultesi Dergisi, Vol. 9(2), p. 16-19.

15. Kingir S., Karakas A., Sengun H.I., Cenberlitas I. (2015) Universite Ogrencilerinin Fast-Food Tercih Etme Sebeplerinin Belirlenmesi: Dicle Universitesi Ornegi. Seyahat ve Otel Isletmeciligi Dergisi, Vol. 12 (3), p. $102-119$.
16. Korkmaz S. (2005) Fast Food (Hizli Yemek) Pazarinda Rekabetci Stratejilerin Etkinligi: Universite Gencliginin Tercihlerinin Analizi. Ticaret ve Turizm Egitim Fakultesi Dergisi, Vol. 2, p. 22-39.

17. Kula S., Cakar B. (2015) Maslow Ihtiyaclar Hiyerarsisi Baglaminda Toplumda Bireylerin Guvenlik Algisi ve Yasam Doyumu Arasindaki Iliski. Bartin Universitesi Iktisadi Idari Bilimler Fakultesi Dergisi, Vol. 6(12), p. 191-210.

18. Lassen A.D., Lehmann C., Andersen E.W., Werther M.N., Thorsen A.V., Trolle E., Gross G., Tetent I. (2016) Gender differences in purchase intentions and reasons for meal selection among fast food customers - opportunities for healthier and more sustainable fast food. Food Quality and Prefence, Vol. 47, p. 123-129.

19. Lin F.Y. (2003) An analysis of hospitality consumer lifestyles in The United States. Ph.D. Dissertation, Texas Tech University, p.14-15.

20. Madran C., Kabakci S. (2002) Tuketici Davranislarini Etkileyen Bir Faktor Olarak Yasam Tarzi: Cukurova Universitesinde Okuyan Kiz Ogrencilerin Yasam Tarzi Tiplerinin Belirlenmesine Yonelik Bir Arastirma. Dokuz Eylul Universitesi Iktisadi Idari Bilimler Fakultesi Dergisi, Vol. 17(1), p. 81-94.

21. Morse K.L., Driskell J.A. (2009) Observed sex differences in fast-food consumption and nutrition self-assessments and beliefs of college students. Nutrition Research, Vol. 29(3), p. 173-179.

22. Mucuk I. (2010). Pazarlama Ilkeleri. Istanbul: Turkmen Kitabevi, $432 \mathrm{p}$.

23. Odabasi Y., Baris G. (2013) Tuketici Davranisi. Istanbul: Mediacat Yayinlari, $404 \mathrm{p}$.

24. Ozgul E. (2010) Tuketicilerin Deger Yapilari, Gonullu Sade Yasam Tarzi ve Surdurulebilir Tuketim Uzerindeki Etkileri. Hacettepe Universitesi Iktisadi ve Idari Bilimler Fakultesi Dergisi, Vol. 28(2), p. 117-150.

25. Plummer J.T. (1974) The concept and application of life style segmentation. Journal of Marketing, Vol. 38(1), p. 33-37.

26. San Z. (2009) Tuketicilerin Yasam Tarzlari ile Fast Food Restoranlarindaki Hizmet Kalitesi Algilamalari Arasindaki Iliski Uzerine Bir Arastirma. MSc. Thesis, Sakarya Universitesi Sosyal Bilimler Enstitusu, Sakarya, p. $48-61$.

27. Tengiz Z.M. (2018) Universite Ogrencilerinin Fast Food Tuketimine Yonelik Tutum ve Davranislarinin Degerlendirilmesi, MSc. Thesis, Namik Kemal Universitesi. Fen Bilimleri Enstitusu, Tekirdag, p. 55-78.

28. Valentine D.B., Powers T.L. (2013) Generation Y values and lifestyle segments. Journal of Consumer Marketing, Vol. 30(7), p. 597-606.

29. Vogli R.D., Kouvunen A., Gimeno D. (2014) The influence of market deregulation on fast food consumption and body mass index: A cross-national time series analysis. Bullerin of the World Health Organization, Vol. 92(2), p. 92-99.

30. Wyne M., Lee M.J., Moon S.J. (1994) Fast food consumption in South Korea. Journal of Consumer Studies and Home Economics, Vol. 18(3), p. 279-291.

31. Yesiloglu H. (2013) Yasam Tarzinin Musteri Sadakati ve Tuketicilerin Satin Alma Davranislari Uzerine Etkileri: Organik Gida Urunlerini Kullanan Tuketiciler Uzerinde Bir Uygulama. MSc. Thesis, Atilim Universitesi Sosyal Bilimler Enstitusu, Ankara, p. 10-15. 